\section{Pharmaceutical companies profit from Japan's blood boom}

\section{Tokyo}

Profiteering by pharmaceutical comanies and hospitals at the expense of patients and the national health insurance system may be behind Japan's skyrocketing consumption of blood plasma, according to an investigation by Japan's Mainichi newspaper.

Japan has already been severely criticized by the World Health Organization for its excessive blood imports, which monopolize about a third of the world market (Nature 317, 101; 1987). Japan's consumption of blood plasma soared to nearly 4 million litres per year in 1985 , nearly all of it imported from the United States. Per capita consumption of blood plasma is about three times that of Britain (see figure).

The Ministry of Health and Welfare has tried to curb use of imports by doubling the volume of blood allowed to be taken from Japanese donors and by issuing guidelines to try to prevent excessive prescription of blood products by the medical profession. But there has been only a slight drop in consumption.

A number of a factors lie behind the import boom. Cheap imports of concentrated blood coagulants for the treatment of haemophiliacs came on the market in 1978 and quickly replaced cryoprecipitate which had to be made from fresh domestic blood. The new coagulants could be selfadministered and sales soared as haemophiliacs began storing them in their refrigerators at home.

Even when it became apparent in the United States in 1983 that AIDS could spread through the use of these coagulants and the United States and Europe turned to heat-treated products, Japan's imports of the untreated coagulants continued to rise, reaching a peak in 1985 when heattreated products were finally allowed on the market. Meanwhile, many of Japan's haemophiliacs are believed to have been infected with AIDS (Nature 331, 552; 1988).

Also behind the blood boom has been increased use of albumin as a 'nutrient' for Japan's rapidly increasing population of elderly people. But the prime driving force behind the rise in use of blood products, according to the Mainichi, has been enormous discounts offered by the pharmaceutical companies.

The Ministry of Health and Welfare sets 'official' prices for all drugs sold in Japan. But, according to the Mainichi, the pharmaceutical companies have been selling blood products to hospitals at $35-85$ per cent below the official price. As the prescription charges for patients and the national health insurance system are based on the official price, the hospitals have been able to reap enormous profits by prescribing more and more blood products, the newspaper charges.

On Monday, a ministry official would neither deny or confirm the Mainichi report. He said that it was "under study". But the official did say that the prices charged by the pharmaceutical companies are a matter for them to decide.

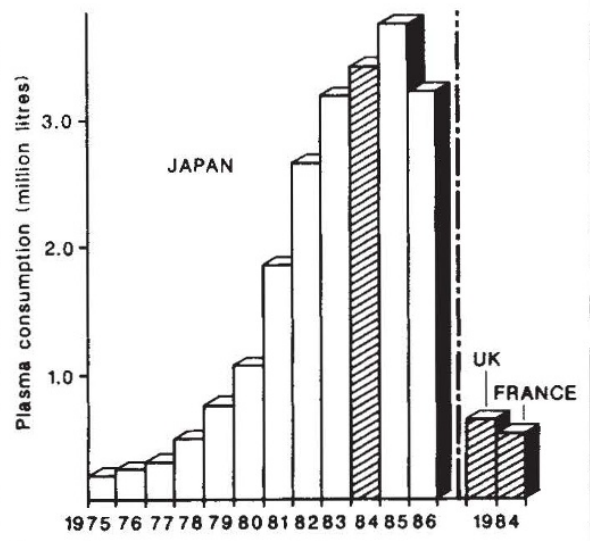

Japan's consumption of blood plasma.

How could the companies offer such large discounts? According to the Mainichi, in 1985 non-heat-treated coagulants could be bought in bulk in the United States for as little as a fifth of the official price in Japan and in that year imports reached a peak of nearly 160,000 bottles.

Clearly the "official" prices of blood products in Japan need to be re-examined and prescription of blood products strictly controlled. The dangers of AIDS infection have been greatly reduced through blood screening and the use of heattreated coagulants, but infection is still possible with hepatitis non-A non-B which is not killed by heat treatment.

The national health insurance system is already in trouble, with income failing to cover expenditure, so the incentive for the ministry to slash excessive use of expensive blood products is strong. But, instead, the ministry's policy is to increase domestic production of blood plasma.

The ministry hopes to secure one million litres of plasma by 1990 through increased blood donations. But already over 8 million people, seven per cent of Japan's population, donate blood each year, a very high rate of donation.

So why does the ministry not simply slash Japan's blood plasma consumption to internationally acceptable levels? The ministry's scientific committees are manned by medical doctors who often collaborate with pharmaceutical companies in research. It is these doctors and the pharmaceutical companies who really determine policy.
Launch of Ariane boosts flagging \section{telecommunications}

\section{Paris}

DURING the night of 11 March, Arianespace, Europe's commercial space consortium, successfully put French and US telecommunications satellites into orbit from an Ariane-3 rocket.

The launch, the twenty-first since the Ariane programme was set up by the European Space Agency in 1973, will bring much-needed relief on both sides of the Atlantic. While French telecommunications has been beleaguered since the Telecom 1B satellite broke down on 15 January (see Nature 331, 469; 1988), the grounding of the Challenger shuttle has meant that no US commercial satellites have been launched in two years.

Telecom 1C, the French satellite on board Ariane flight V21, will replace the failed Telecom 1B and will take the strain off the ageing Telecom $1 \mathrm{~A}$, which has to take the extra traffic as an interim measure. For the past two months, Telecom 1A has been relaying all French radio and television broadcasts, military communications and overseas telephone calls - a task which it could not continue to handle without shortening its life.

Engineers at Matra, the French manufacturers of Telecom 1C, will still be biting their nails, however. The satellite is essentially a duplicate of its failed predecessor, although it was sent back from the Arianespace launch site in French Guiana for thorough testing in February, delaying the V21 launch. Last month the West German telecommunications department had to abandon its brand-new direct-broadcast television satellite, TV-SAT, which failed to come on stream despite a faultless Arianespace launch.

The other satellite put into orbit on flight V21, Spacenet IIIR/Geostar, belongs to the US telecommunications company, GTE Spacenet. Geostar is a radiolocalization satellite, immediately destined for use by road and rail transport companies, but likely to be extended for use by shipping. Since the mid-flight explosion of the US National Space and Aeronautics Administration (NASA) Challenger shuttle in 1986, only military payloads have been put into space on US rockets. NASA now hopes to resume scientific and commercial satellite launches this summer (see Nature 330, 195; 1987).

Having got back into its stride after the setbacks of the past two years, Arianespace intends to keep up the pace with 8 launches scheduled for 1988 and 9 each year until 1990. The company has a backlog of 43 satellites, worth over $\$ 2,600$ million.

Peter Coles 